Kokocinska, M., Puziak, M. (2018). Regional Income Differences and their Evolution after EU Accession. The Evidence from Visegrad Countries. Journal of Competitiveness, 10(4), 85-101. https://doi. org/10.7441/joc. 2018.04 .06

\title{
REGIONAL INCOME DIFFERENCES AND THEIR EVOLUTION AFTER EU ACCESSION. THE EVIDENCE FROM VISEGRAD COUNTRIES
}

\section{- Matgorzata Kokocinska, Marcin Puziak}

\begin{abstract}
The aim of this paper is to determine the regional convergence process in Visegrad (V4) economies after their accession to the EU at the NUTS3 level. The study uses kernel density estimation for 114 regions in V4 countries. The research period covered the years 2004-2015. The results show that all V4 economies except for Hungary reduced the distance to the EU-28 average over the period considered. The external convergence process was accompanied by an increase in income inequalities at the regional level. In all the countries, the estimated distributions of regional income were bimodal, with the clearly marked second mode related to the capital region. The obtained research results should be an indication of economic decisions in the context of regional (also known as cohesion) policy and economic competitiveness. This paper contributes to the existing literature in three ways. First, the study was conducted at the NUTS3 level, which is currently the lowest possible level of disaggregation. Second, the analysis covered both the period before and after the global financial crisis. Third, the results of the internal convergence study are not biased by the method used, as this method has already been tested in previous research for a group of large European economies.
\end{abstract}

Keywords: income distribution, regional convergence, Visegrad countries, inequality, competitiveness JEL Classification: D31, O47, P48, R11

Received: July, 2018

1st Revision: October, 2018

Accepted: October, 2018

\section{INTRODUCTION}

Increasing inequalities, in particular income inequality and wealth inequality, are currently regarded as one of the major economic and social problems in the world. These inequalities concern both advanced and catching-up economies, a situation which influences the fact that the research on $\beta$ and $\sigma$ convergence is increasingly being undertaken at different levels of analysis. Results, however, have been ambiguous. The concept of convergence, based on a hypothesis by Williamson (1965) that the initial rapid economic growth of an entire economy is related to the growing inequalities that will disappear after crossing a certain threshold, has not been confirmed in a robust manner. Thus, the problem of the mutual relationship between external and internal convergence is still considered as controversial. Among the highly developed econo- 
mies, one can observe various bimodal types of income distribution which have developed over the long term and which cannot be treated as simply the price that has to be paid in exchange for the catching-up process.

These observations for developed economies have led to the question of whether such a situation in terms of income distribution is present in the V4 countries, which are close to each other in terms of the level of development, mutual economic cooperation as well as the historical determinants of transformation after their concurrent entry into the European Union in 2004. An important factor in such an analysis may be the fact that all of these countries were characterized by a significant number of poor regions which were beneficiaries of the EU's cohesion policy.

The aim of this article is to determine the regional convergence process in Visegrad (V4) economies after their accession to the EU, in particular taking into account the evolution of income distribution at the NUTS3 region level. The rationale for the analysis at the NUTS3 level lies is the fact that only Poland contains the sufficient number of NUTS2 level regions to conduct such research. This study covered 114 regions in the V4 countries, including 72 in Poland, 14 in the Czech Republic, 20 in Hungary and 8 in Slovakia.

\section{THEORETICAL BACKGROUND}

Economic growth is one of the main areas of interest in both scientific research and economic policy. This means that the process of economic growth is a subject of interest in both positive and normative economics. The nature of economic growth compels comparisons among various countries or regions. In other words, an assessment of economic growth is not possible without a specific benchmark.

In the context of economic growth, and in particular in the context of empirical research, it should be noted that current research on economic growth is closely related to the analysis of the convergence process. The term "convergence," understood as the process of poorer countries catching up with richer ones, appeared in literature on economic growth in the second half of the 1980s thanks to Abramovitz (1986) and Baumol (1986) along with the subsequent scientific debate between De Long (1988) and Baumol \& Wolff (1988). These authors investigated whether there is a tendency according to which countries (regions) initially poorer develop faster than countries (regions) initially richer. Convergence literature was significantly enriched at the beginning of the 1990s, especially by Mankiw, Romer, \& Weil (1992), by Barro \& Sala-iMartin (1992) and also by Islam (1995), who was one of the first to use panel methods to study convergence. The latter paper by Barro \& Sala-i-Martin is particularly important because the authors derived their equation of convergence from the neo-classical Solow growth model and introduced the distinction into $\beta$-convergence and $\sigma$-convergence. The first concept focuses on comparing the economic growth rate of countries or regions which are initially at different level of development, while the second concept focuses on the study of income differences in the group of countries or regions.

Since the publications of the early 1990s, there has been a significant increase in the number of works on economic growth and convergence. In addition, the focus of country research has been 
shifted to regional studies. The standard models consisted of the analysis of convergence among US states and prefectures in Japan (Barro \& Sala-i-Martin, 1992), and convergence among European regions (Barro \& Sala-i-Martin, 1991). The convergence literature in European regions, a very popular research area, is particularly important for the problem discussed in this paper. After the 2004 enlargement of the European Union a significant increase in the number of studies can be noted.

Based on a review of the literature carried out by Kokocińska \& Puziak (2018), it can be concluded that the great interest in this subject resulted mainly from three events. Firstly, since the 1970s, subsequent waves of enlargement of the European Union have taken place which led to the inclusion of countries with a significantly different levels of development. In particular, the 2004 enlargement was the greatest challenge to the cohesion policy in the history of the European Union. Secondly, the signings of the Single European Act (SEA) in 1986 and the Maastricht Treaty in 1992 constituted Cohesion Policy aimed to promote harmonious overall community development and to pursue actions leading to the strengthening of economic and social cohesion by reducing disparities between the various regions and the backwardness of least-favoured regions (European Economic Community, 1987). Thirdly, the seminal event of the global financial crisis of 2008-2009 led to the focus of process convergence research on the two periods of before and after the crisis. The prevailing conclusions reached forced researchers to re-verify the convergence hypothesis. Moreover, assessments of European Union cohesion policy on reducing development disparities have produced results which are ambiguous at best.

A great deal of research on convergence has been focused on the V4 countries. These researches, which have intensified since the accession of V4 countries to the EU, have concentrated mainly on the $\beta$ and $\sigma$ convergence processes (Kisiala, Bajerski, \& Stepinski, 2017; Kuc, 2017; Simionescu, 2014), as well as on factors affecting the convergence process and its effects. Among the numerous studies, Ivanová \& Čepel (2018) focused on innovation and competitiveness. Balcerzak \& Pietrzak (2017) concentrated on the digital economy, and Baddeley (2006) focused on the impact of the convergence process on growth and inequality. Horridge \& Rokicki (2018) studied the impact of European Union accession on regional income. It can be concluded that the results of all these research studies confirm external convergence in all V4 countries in the period after the EU accession, while the impact of accession on income inequalities varies, a finding which results from the influence of other factors such as globalization, the digitalization of economies as well as from the general level of competitiveness.

More information about the impact of EU accession on V4 economies can be found in the evaluations of cohesion policy funds which emphasize the benefits obtained by V4 countries in significant areas (Bartkiewicz et al., 2017):

- Cohesion policy brings economic benefits both to its recipients and to its main contributors across EU member states;

- $25-30 \%$ of real V4 GDP convergence with the EU average comes from cohesion policy investments;

- V4 GDP in 2015 was higher by $5.8 \%$ due to cohesion policy intervention; GDP of $40 \%$ of V4 regions were above the $75 \%$ of EU GDP average in 2014; 
- EU-15 has contributed ca. EUR 120 bn to cohesion policy, but has derived economic benefits of ca. EUR 97 bn (2007-15);

- $80 \%$ (EUR $97 \mathrm{bn}$ ) of EU-15 contributions to cohesion policy returned back to their economies (2007-15);

- EU-15 financial contribution to cohesion policy is offset by direct and indirect export benefits, direct capital benefits as well as positive externalities.

The impact and results of cohesion policy in the V4 countries are presented in Table 1.

Tab. 1 - The Effects of Cohesion Policy in the V4 countries. Source: How do EU-15 Member States Benefit from the Cohesion Policy in the V4?

\begin{tabular}{|c|c|}
\hline $\begin{array}{l}\text { Type of Cohesion } \\
\text { Policy intervention }\end{array}$ & Effects of Cohesion Policy in the V4 countries \\
\hline \multirow{3}{*}{$\begin{array}{l}\text { Transport infrastruc- } \\
\text { ture }\end{array}$} & $\begin{array}{l}\text { improved accessibility of V4-regions, EU's most remote areas con- } \\
\text { nected to the European transport system }\end{array}$ \\
\hline & increased safety of the transport system \\
\hline & lower emissions of GHG and lower air pollution \\
\hline \multirow{3}{*}{ Business support } & launch in new products on the market improved product quality, \\
\hline & increased productivity, production and R\&D capacities \\
\hline & increased market share and strengthened competitive position \\
\hline \multirow{4}{*}{$\begin{array}{l}\text { Higher education } \\
\text { and R\&D }\end{array}$} & improved teaching conditions and teaching quality \\
\hline & development of educational facilities \\
\hline & modernisation of the teaching process at existing faculties \\
\hline & extended education offers to new fields of specialisation \\
\hline \multirow{3}{*}{$\begin{array}{l}\text { Energy sector and } \\
\text { environmental pro- } \\
\text { tection }\end{array}$} & $\begin{array}{l}\text { implementation of the EU energy policy and fulfilment of accession } \\
\text { obligations }\end{array}$ \\
\hline & $\begin{array}{l}\text { reduced greenhouse gas emissions and other air pollutions, lower } \\
\text { emissions to surface and groundwater }\end{array}$ \\
\hline & improved quality of living \\
\hline
\end{tabular}

It should be noted that in all the areas of cohesion policy benefits indicated in Table 1, there were also benefits for EU-15. The most important of these include: better access to V4 markets for EU-15 companies, better workforce productivity of V4 located in EU-15 owned companies, extending the possibilities and improving educational offer for students and academics from the EU-15 and the elimination of a potential source and groundwater pollution in the border regions.

In this context, the answer to the question of how the global perspective assessment of the benefits resulting from cohesion policy shifted into the distributions of income in individual economies is crucial. 


\section{RESEARCH OBJECTIVE AND METHODOLOGY}

The subject of this research is the Visegrad Group (V4), in particular the distribution of income at the NUTS3 level since the accession of this group to the EU in 2004 until 2015, the year of the latest statistical data for NUTS3 regions in these countries. The wider context is the analysis of similarities and differences between countries in two groups of selected indicators. The first group of indicators concerns mostly the characteristics of the population, the second concerns the macroeconomic situation. Both groups include selected indicators that are monitored by the EU.

Tab. 2 - Selected indicators - area and population in the Visegrad countries. Source: Statistical Office Poland, 2018, www.stat.gov.pl (access: 03.2018)

\begin{tabular}{|c|c|c|c|c|c|c|c|c|}
\hline \multirow{2}{*}{$\begin{array}{l}\text { Visegrad } \\
\text { Group }\end{array}$} & \multirow{2}{*}{$\begin{array}{l}\text { Area } \\
(1000 \\
\left.\mathrm{km}^{2}\right)\end{array}$} & \multirow{2}{*}{$\begin{array}{l}\text { Popula- } \\
\text { tion } \\
2016 \\
(1000)\end{array}$} & \multicolumn{2}{|c|}{$\begin{array}{l}\text { Life expectancy } \\
\text { in years }\end{array}$} & \multicolumn{2}{|c|}{$\begin{array}{l}\text { Economically ac- } \\
\text { tive population }\end{array}$} & \multicolumn{2}{|c|}{$\begin{array}{l}\text { Employed per- } \\
\text { sons, } 2016\end{array}$} \\
\hline & & & 1995 & 2015 & 2016 & $\%$ & 2016 & $\%$ \\
\hline $\begin{array}{l}\text { Czech } \\
\text { Republic }\end{array}$ & 78.9 & 10562 & 69.7 & 75.7 & 5350 & 50.6 & 5139 & 48.6 \\
\hline Hungary & 93.0 & 9810 & 65.4 & 72.3 & 4586 & 46.7 & 4352 & 44.3 \\
\hline Poland & 312.7 & 38427 & 67.7 & 73.5 & 17260 & 44.9 & 16197 & 42.1 \\
\hline Slovakia & 49.0 & 5429 & 68.4 & 73.1 & 2759 & 50.8 & 2492 & 45.9 \\
\hline
\end{tabular}

Based on the data presented in Table 2, Poland stands out relatively in terms of territorial and population potential. Within two decades, average life expectancy has increased and this is especially important, as life expectancy is dependent on material conditions, which have obviously improved. From the point of view of the economic activity rate, in 2016 Poland showed the relatively lowest indicator, which was lower than the Czech Republic by more than 6 percentage points.

Tab. 3 - Selected indicators - economic situation in Visegrad countries. Source: Statistical Office Poland, 2018, www.stat.gov.pl (access: 03.2018)

\begin{tabular}{|c|c|c|c|c|c|c|}
\hline \multirow[b]{2}{*}{$\begin{array}{l}\text { Visegrad } \\
\text { Group }\end{array}$} & \multicolumn{2}{|c|}{ GDP pc at PPP } & \multirow[b]{2}{*}{$\begin{array}{l}\text { Debt of } \\
\text { the general } \\
\text { govern- } \\
\text { ment sec- } \\
\text { tor (current } \\
\text { prices) } \\
2016\end{array}$} & \multirow[b]{2}{*}{$\begin{array}{l}\text { Surplus } \\
(+) \text {, deficit } \\
(-) \text { of the } \\
\text { general } \\
\text { govern- } \\
\text { ment sec- } \\
\text { tor (current } \\
\text { prices) } \\
2016\end{array}$} & \multirow[b]{2}{*}{$\begin{array}{l}\text { Gross } \\
\text { domestic } \\
\text { expendi- } \\
\text { ture on re- } \\
\text { search and } \\
\text { develop- } \\
\text { ment activ- } \\
\text { ity (R\&D) } \\
2016\end{array}$} & \multirow[b]{2}{*}{$\begin{array}{l}\text { Share of } \\
\text { renewable } \\
\text { energy in } \\
\text { gross final } \\
\text { energy } \\
\text { consump- } \\
\text { tion } 2015\end{array}$} \\
\hline & 2004 & 2015 & & & & \\
\hline $\begin{array}{l}\text { Czech } \\
\text { Republic }\end{array}$ & 21945,2 & 25272,5 & 36,8 & 0,7 & 1,68 & 15,1 \\
\hline Hungary & 20622,3 & 19744,2 & 73,9 & $-1,9$ & 1,21 & 14,5 \\
\hline
\end{tabular}




\begin{tabular}{|l|l|l|l|l|l|l|}
\hline Poland & 14381,0 & 20082,0 & 54,1 & $-2,5$ & 0,97 & 11,8 \\
\hline Slovakia & 16168,2 & 22292,4 & 51,8 & $-2,2$ & 0,79 & 12,9 \\
\hline
\end{tabular}

In the period 2004-2015, Poland, the Czech Republic and Slovakia experienced economic growth and as a result, GDP pc increased 1.4 times during this period in Poland and Slovakia, while the largest increase was observed in the Czech Republic (1.6 times). Only Hungary recorded GDP pc decline in the period under consideration. The Czech Republic remained the clear leader, accounting also for other indicators. In 2016, the Czech Republic had the lowest public debt among the V4 countries, as well as the only economy with a budget surplus. The Czech Republic leads in $\mathrm{R} \& \mathrm{D}$ expenditure and has the highest share in renewable energy in comparison to the other V4 countries. Despite the historical similarity, the situation of the Czech Republic in 2016 was clearly better than in other countries. This is confirmed by the dynamics of GDP pc in the period 2004-2015 against the background of EU-28, which is shown in Figure 1.

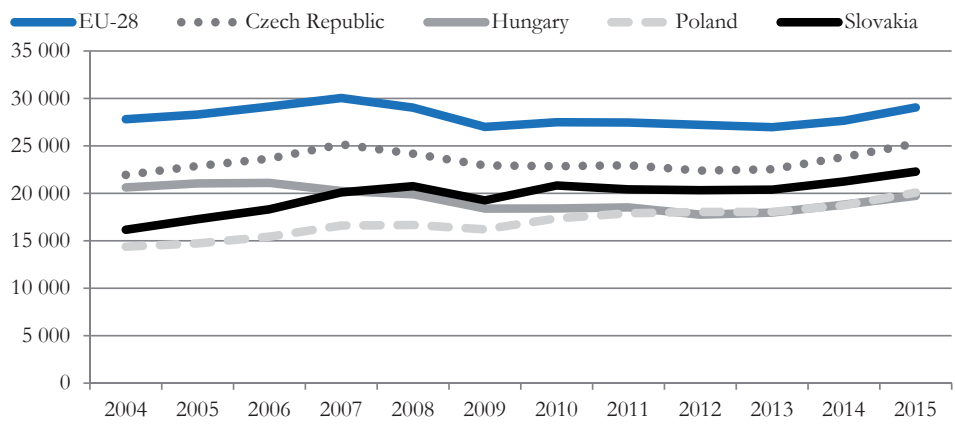

Fig. 1 - GDP pc 2004 - 2015 in the Visegrad countries. Source: Own calculations based on Eurostat database (access: 03.2018).

Except for Hungary, GDP pc growth over time was similar to the changes in the EU-28, with all countries showing a clear impact from the global financial crisis. After 2009, there was a noticeable decrease in differences of GPD pc level among countries, which proves the occurrence of external convergence. One can agree with the statement of Kuc (2017) that "..social development is not enough to achieve social $\sigma$ convergence. That should not be surprising as an unconventional 'union convergence machine'...". This leads to the conclusion that it is important to link the processes of external and internal convergence. The most expected tendency would be the existence of both processes at the same time. In order to adequately assess the occurrence of internal convergence/divergence at the level of regions, an in-depth analysis should be made which, in addition to simple measures, is capable of identifying the distribution of income. Such an analysis refers back to Williamson's concept, and confirms whether or not V4 countries have paid the price for rapid economic growth in the form of growing inequalities, and if so, what is the scale.

In order to determine the dispersion level of GDP pc among the regions of the country, the standard deviation is usually used, however, it is a measure that detects the absolute differences in the distribution of the given feature. The phenomenon of the increasing level of standard de- 
viation determined on the basis of the GDP pc levels of the NUTS3 regions for the economies studied may suggest the occurrence of a $\sigma$ divergence process, but it is worth noting that the increasing level of the standard deviation can be solely the result of the rise in the average level of GDP pc. In order to eliminate the potential error in the interpretation of the $\sigma$ convergence, the coefficient of variation is used, which has the advantage of detecting the relative variation of the features (in this case, GDP pc). The coefficient of variation that decreases with time means that $\sigma$ convergence process is observed.

Simple $\sigma$ convergence measures, such as standard deviation and coefficient of variation provide relevant information, however, such an approach may also be considered as insufficient (Quah, 1993; Wójcik, 2004). It seems much more interesting the analysis of the dynamics of distribution of the variable and internal mobility within it over time (Wójcik, 2016). It is possible to perform such an analysis by applying kernel density estimation. Consequently, an attempt was made to estimate the distribution of domestic income based on observations of the average GDP pc in the NUTS3 regions. The importance of the given NUTS3 region in the country was based on the population of the region. Such an approach, at least in part, denies the excessively restrictive hypothesis of being able to identify the income of the citizen with the average income of the region. In order to reproduce the distribution of income, the nonparametric method has been used, which has the advantage of abstracting from the assumption of the arbitrary form of distribution function. The idea of using the kernel density estimator consists of reproducing the distribution in the population through the punctual information of the probability distribution in the closest surroundings of the point. The kernel density estimator for the function $\mathrm{K}$ takes the following form

$\widehat{f_{k}}=\frac{1}{q h} \sum_{i=1}^{n} w_{i} K\left(\frac{x-X_{i}}{h}\right)$

where:

$n$ - the number of points at which the density estimate is to be evaluated;

$q=\sum_{i} w_{i}=n$, which means that analytic weights were used,

$x-X_{i}-$ the width of the density window around each point,

$h$ - smoothing parameter of the function $f_{k}$.

The study used the Epanechnikov function (1969), which is characterized by the minimum mean integrated squared error and takes the following form:

$K[z]=\left\{\begin{array}{c}\frac{3}{4}\left(1-z^{2}\right),|z|<1 \\ 0,|z| \geq 1\end{array}\right.$

There is the opinion that the choice of the $\mathrm{K}$ function is not as critical as the selection of adequate bandwidth (b) (see Heidenreich, Schindler, \& Sperlich, 2010; Zambom \& Dias, 2013). The choice of bandwidth determines the degree of smoothing of the density graph. Marking the scale that is too wide affects the excessive smoothing, so that the local ends can not be observed. In turn, the use of the window which is too narrow would make interpretation difficult, since the density function would have many narrow peaks and valleys between them (Wójcik, 2016). In the analysis, the $h$ parameter was determined arbitrarily according to the prevailing opinion in the literature (see Sala-i-Martin, 2006) 
$h=\frac{0,9 \sqrt{\sigma^{2}}}{\sqrt[5]{n}}$

where:

$\sqrt{\sigma^{2}}$ - standard deviation weighted by the population of each region.

From the point of view of interpretation, it is important to link the aforementioned measures and consider the relative correspondence between them. In this paper, coefficient of variation is used as the most representative simple measure, and as its complement, which is the estimated income distribution.

\section{RESULTS AND DISCUSSION}

Tables 3 to 6 present information on the average level of GDP pc calculated for a given country using the arithmetic average weighted by a population of a given NUTS3 region; standard deviation, also weighted by the population of the given NUTS3 region; coefficient of variation; value of GDP pc for the poorest region (min), value of GDP pc for the richest region (max); MM measure, which is the value of the GDP pc of the poorest region in relation to the richest region and the AM measure, which is the average value of GDP pc in relation to the richest region. All measures were presented for the years 2000, 2004, 2008 and 2015, which were considered as turning points, carrying the largest interpretive load.

The verification of the $\sigma$ convergence hypothesis (regional disparities) is carried out on the basis of three measures: the coefficient of variation, the MM measure and the AM measure. In the case of the coefficient of variation $\sigma$, the convergence is confirmed when the coefficient of variation decreases over time. In the case of the MM measure, the value of which must be between $0 \%$ and $100 \%$, an increase in value means that the gap between the poorest and richest region is diminishing, which may indirectly indicate $\sigma$ convergence. In the case of the AM measure, which value must be between $0 \%$ and $100 \%$, the increase in value means that the gap between the richest region and the average GDP of pc determined on the basis of all regions of the country decreases, which is consistent with the $\sigma$ convergence.

Tab. 3 - Selected measures describing the level of the regional GDP pc level and its diversification in the Czech Republic in selected years [data in EUR according to PPS (2015=100)]. Source: Own calculations based on Eurostat database (access: 03.2018)

\begin{tabular}{|l|l|l|l|l|}
\hline Measure & 2004 & 2008 & 2012 & 2015 \\
\hline average & 22128.65 & 24163.48 & 22446.30 & 25279.49 \\
\hline standard deviation & 9294.86 & 10922.40 & 9437.03 & 10843.27 \\
\hline coefficient of variation & $42.00 \%$ & $45.20 \%$ & $42.04 \%$ & $42.89 \%$ \\
\hline $\min$ & 17206.98 & 17032.97 & 15816.33 & 16900.00 \\
\hline $\max$ & 46134.66 & 52417.58 & 46836.73 & 53200.00 \\
\hline $\mathrm{MM}(\mathrm{min} / \mathrm{max})$ & $37.30 \%$ & $32.49 \%$ & $33.77 \%$ & $31.77 \%$ \\
\hline $\mathrm{AM}(\operatorname{avg} / \max )$ & $47.97 \%$ & $46.10 \%$ & $47.92 \%$ & $47.52 \%$ \\
\hline
\end{tabular}


In the analysed period, the average GDP pc in the Czech Republic increased, with a certain breakdown after the global financial crisis, which indicates that there was an economic growth. At the same time, the standard deviation increased, but slower than the average, which does not entitle to state that the differences in the GDP pc level were growing over time at the regional level. As a result, the relative income differences measured by the coefficient of variation had a downward trend. However, the results are not statistically significant, which does not allow to clearly state the existence of the $\sigma$ convergence process. The MM measure of the relative distance between the poorest and richest region had decreased from 37.3\% in 2004 to 31.8\% in 2015. The AM measure, in turn, informing about the ratio of the average GDP pc in comparison to the richest region remained at a similar level of all the years in the researched period.

Tab. 4 - Selected measures describing the level of the regional GDP pc level and its diversification in Hungary in selected years [data in EUR according to PPS (2015=100)]. Source: Own calculations based on Eurostat database (access: 03.2018)

\begin{tabular}{|l|l|l|l|l|}
\hline Measure & 2004 & 2008 & 2012 & 2015 \\
\hline average & 20982.32 & 20196.72 & 17892.68 & 19769.15 \\
\hline standard deviation & 10918.24 & 11799.31 & 10380.71 & 10400.73 \\
\hline coefficient of variation & $52.04 \%$ & $58.42 \%$ & $58.02 \%$ & $52.61 \%$ \\
\hline min & 10951.10 & 9132.98 & 7837.95 & 8500.00 \\
\hline max & 42904.29 & 44081.83 & 38884.36 & 40300.00 \\
\hline MM (min/max) & $25.52 \%$ & $20.72 \%$ & $20.16 \%$ & $21.09 \%$ \\
\hline AM (avg/max) & $48.90 \%$ & $45.82 \%$ & $46.02 \%$ & $49.05 \%$ \\
\hline
\end{tabular}

In Hungary, as in the Czech Republic, the clearly negative impact of the crisis on the economic growth was observed. This impact was so strong that the average GDP pc in 2015 was at a lower level than in 2004. The standard deviation generally remained at a similar level during the researched period. The coefficient of variation, after a marked increase initiated with the crisis, returned to its initial level in the final year of the analysis. However, in comparison with the Czech Republic, it is at a definitely higher leveIn relation to the Czech Republic, the results are not statistically significant, which does not allow to confirm the occurrence of the $\sigma$ convergence process. Although the trends of the MM and AM measures are not unequivocal, these measures reacted strongly to the crisis in a negative manner, but in the final year of the analysis there are some signs of weak positive signals. The initial (2004) average GDP pc level in relation to the richest region was again reached in 2015. The levels of the GDP pc in Hungary are significantly lower to those observed in the Czech Republic, in particular in case of the poorest regions. In Hungary, the GDP pc level in the poorest region is approximately two times lower than in the Czech Republic. 
Tab. 5 - Selected measures describing the level of the regional GDP pc and its diversification in Poland in selected years [data in EUR according to PPS (2015=100)]. Source: Own calculations based on Eurostat database (access: 03.2018)

\begin{tabular}{|l|l|l|l|l|}
\hline Measure & 2004 & 2008 & 2012 & 2015 \\
\hline average & 16930.87 & 17616.52 & 18146.34 & 19831.62 \\
\hline standard deviation & 7963.25 & 8514.93 & 9343.10 & 10063.13 \\
\hline coefficient of variation & $47.03 \%$ & $48.33 \%$ & $51.49 \%$ & $50.74 \%$ \\
\hline $\min$ & 10051.01 & 10472.48 & 9670.20 & 10400.00 \\
\hline $\max$ & 46504.65 & 49439.84 & 52829.80 & 56900.00 \\
\hline $\mathrm{MM}(\min / \max )$ & $21.61 \%$ & $21.18 \%$ & $18.30 \%$ & $18.28 \%$ \\
\hline AM (avg/max) & $36.41 \%$ & $35.63 \%$ & $34.35 \%$ & $34.85 \%$ \\
\hline
\end{tabular}

All the measures used in case of Poland indicate a coherent picture of the $\sigma$ divergence process. In the analysed period, average GDP pc was growing systematically without showing a significantly negative impact from the crisis, i.e. with a simultaneous faster growth with standard deviation. In addition, the coefficient of variation showed an upward trend, slightly decreasing in 2015 . The relation of these measures indicates the divergence process at the regional level, a finding which is confirmed by the decreasing MM and AM measures. While in 2004 GDP pc in the poorest region in relation to the richest was $21.6 \%$, in 2015 it fell to $18.3 \%$. The measure of the average GDP pc in relation to the GDP pc for the richest region only slightly increased in 2015.

Tab. 6 - Selected measures describing the level of the regional GDP pc level and its diversification in Slovakia in selected years [data in EUR according to PPS (2015=100)]. Source: Own calculations based on Eurostat database (access: 03.2018)

\begin{tabular}{|l|l|l|l|l|}
\hline Measure & 2004 & 2008 & 2012 & 2015 \\
\hline average & 16433.13 & 21524.79 & 20268.56 & 22283.35 \\
\hline standard deviation & 8219.08 & 11379.77 & 11498.25 & 12708.62 \\
\hline coefficient of variation & $50.02 \%$ & $52.87 \%$ & $56.73 \%$ & $57.03 \%$ \\
\hline min & 9808.92 & 12557.60 & 11923.85 & 13300.00 \\
\hline $\max$ & 36942.68 & 49654.38 & 48897.80 & 54200.00 \\
\hline MM (min/max) & $26.55 \%$ & $25.29 \%$ & $24.39 \%$ & $24.54 \%$ \\
\hline AM (avg/max) & $44,48 \%$ & $43,35 \%$ & $41,45 \%$ & $41,11 \%$ \\
\hline
\end{tabular}

In Slovakia, the average level of GDP pc in the analysed period increased dynamically before the beginning of the crisis and again after 2012. The rapid growth between 2004 and 2008 may have resulted from macroeconomic stability policy related to Maastricht criteria aimed at the adoption of the euro, which certainly increased competitiveness as a whole. This was accompanied by the faster increase in standard deviation, which negatively affected the coefficient of variation, which was also increasing. These observations indicate the processes of regional divergence. The 
MM and AM measures do not show the desired upward trends. In 2015, the GDP pc level in the poorest region was $24.5 \%$ of the richest region, and the level of average GDP in relation to the richest region systematically decreased in the analysed period and shaped in 2015 at a level slightly above $40 \%$ of the GDP of the richest region.

Tab. 7 - Selected measures of the GDP pc in the V4 countries at NUTS3 regional level.in 2015. Source: Own calculations based on Eurostat database (access: 03.2018)

\begin{tabular}{|l|l|l|l|l|}
\hline Measure & $\begin{array}{l}\text { Czech } \\
\text { Republic }\end{array}$ & Hungary & Poland & Slovakia \\
\hline $\min$ & 16900.00 & 8500.00 & 10400.00 & 13300.00 \\
\hline $\max$ & 53200.00 & 40300.00 & 56900.00 & 54200.00 \\
\hline $\mathrm{MM}(\min / \max )$ & $31.77 \%$ & $21.09 \%$ & $18.28 \%$ & $24.54 \%$ \\
\hline $\mathrm{AM}(\mathrm{avg} / \max )$ & $47.52 \%$ & $49.05 \%$ & $34.85 \%$ & $41.11 \%$ \\
\hline
\end{tabular}

Table 7 reports the selected measures of regional disparities which have been formed for more than a decade after the accession of V4 countries to the European Union. These data allow to directly compare the GDP pc level in the poorest and richest regions in absolute numbers, as well as the relation of the average GDP pc level to the richest region. This comparison indicates a diverse situation in the analysed countries and the strength of the changes in cases in which each measure is different. There is a significant gap between the Czech Republic and other Visegrad countries in terms of GDP pc levels, in particular in the poorest regions. In Hungary, the GDP pc level in the poorest region is approximately two times lower than in the Czech Republic. The average level of GDP pc in the richest region is also significantly lower in Hungary in comparison to other countries.

The MM measure indicates that the largest disparities in income were observed in Poland and Hungary. The AM measure indicates the largest disparity in income, observed in Poland and Slovakia. What might be surprising is that the AM measure is relatively the best in Hungary.

In addition to the information presented in Tab. 7., Fig. 2 illustrates the changes in the coefficient of variation over the researched period. The graph for each country has the same scale on the vertical axis, which allows the comparison of both the level and the trend in the coefficient of variation. 


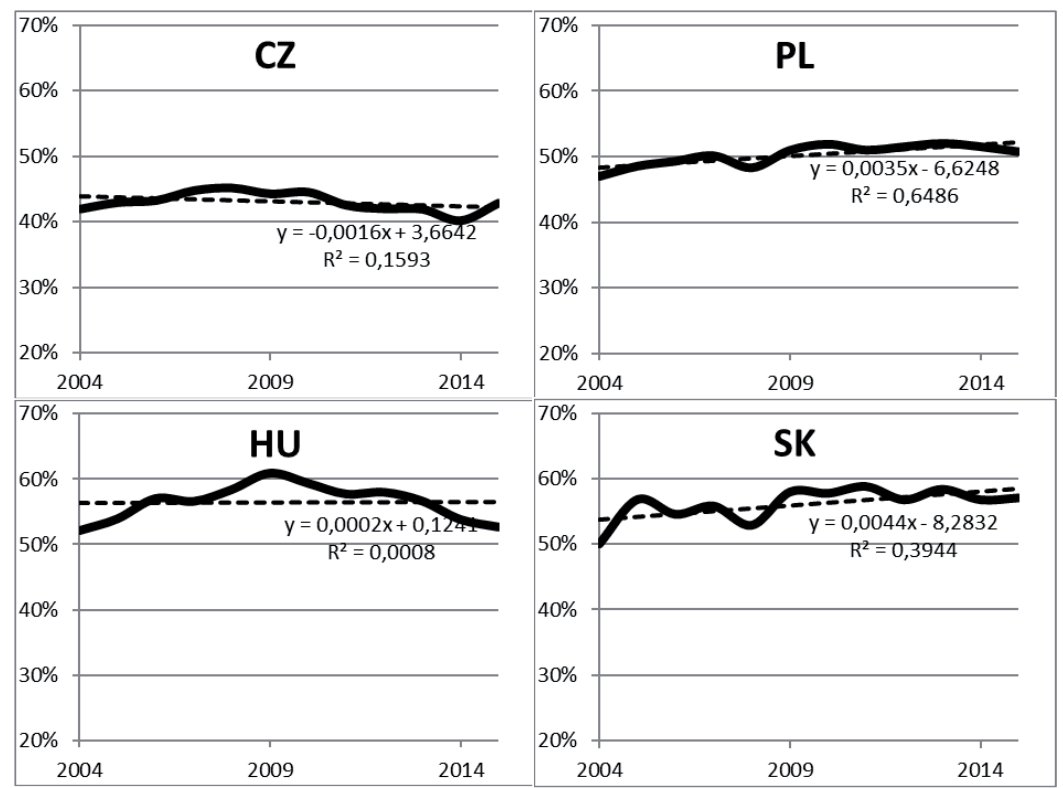

Fig. 2 - Income differences in the V4 countries measured by the coefficient of variation in the period 2004-2015. Source: Own calculations based on Eurostat database (access: 03.2018)

From the coefficient of variation perspective, the threshold level may reach $50 \%$. The observations of this indicator show that the only economy with a coefficient of variation below this level was the Czech Republic. The highest average coefficient of variation was observed in Hungary and Slovakia, however, in the case of the Czech Republic and Hungary, the estimated trend is not statistically significant. Therefore, in these cases the convergence hypothesis cannot be statistically rejected. In the case of Poland, one can identify $\sigma$ divergence at the $1 \%$ level of significance, with very high R2, and in Slovakia, $\sigma$ divergence at 10\% significance level (also with high R2). In these two countries (Poland and Slovakia), the dissonance between the external and internal convergence was most evident. This means that the catching-up process at the country level has taken place at the price of the increasing income inequalities at the regional level.

Indeed, the observation of the coefficient of variation is highly insufficient. The estimation of income distributions at the NUTS3 regions level should be the key to assessing the internal convergence process. The results of such estimations are presented in Fig. 3. 


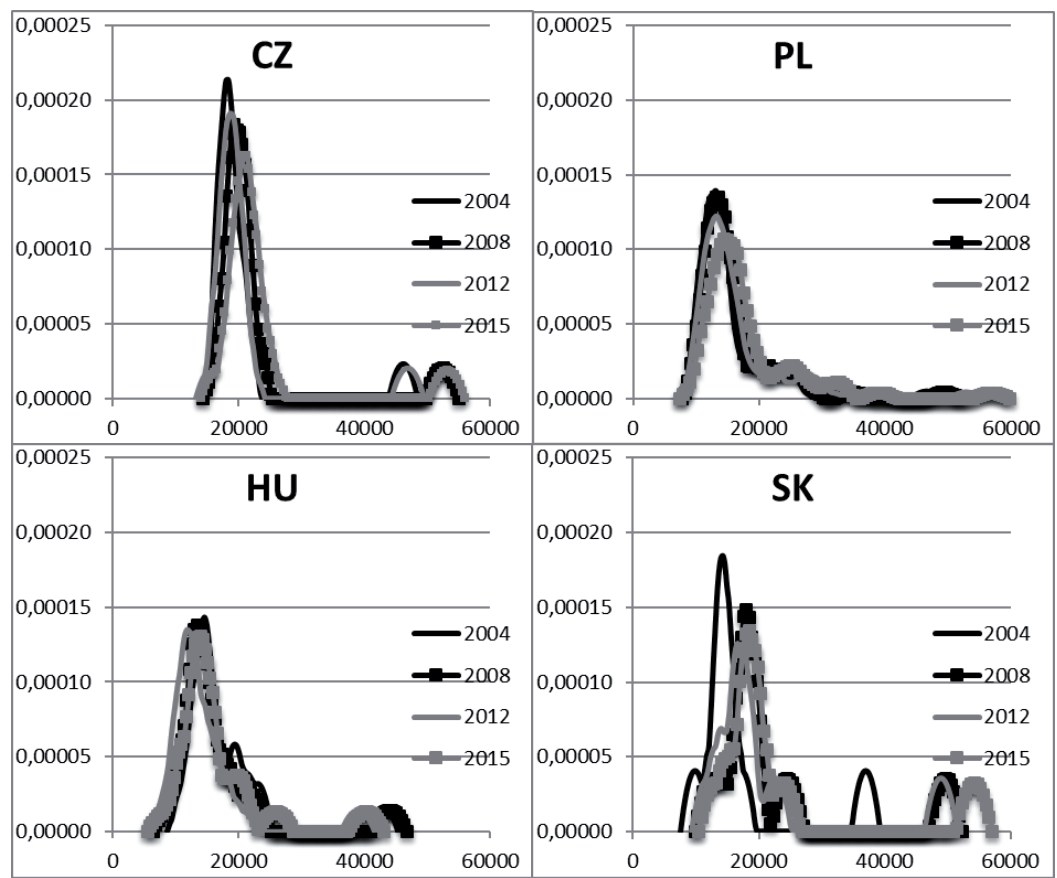

Fig. 3 - Regional income density functions in the V4 countries in selected years ( $x$-axis - income measured in thousands of EUR in PPS at 2015 prices; $y$-axis - density). Source: Own calculations based on Eurostat database (access: 03.2018)

The interpretation of the situation observed in the graph can be undertaken from various points of view:

- firstly, the assessment should be made as to whether the resulting distribution is similar to a unimodal distribution, or if more than one extreme was shown, the distribution can be bimodal or multimodal;

- secondly, the shape, and more specifically the curiosity of the graph, is evaluated, which provides information about the concentration of observations around the dominant;

- thirdly, the shift and the scale of the shift over time are assessed. The desirable shift is the move to the right, which means that there is economic growth (the level of GDP pc is marked on the vertical axis);

- fourthly, based on the observation of the direction and the scale of the shift, one can also infer whether the right side of the graph, associated with the richer regions with the left side associated with the poorer regions, moved at a similar pace regardless of the shape of the distribution function.

Based on observations made regarding large European economies such as Germany, France, Italy, Spain and the United Kingdom, three models of regional distribution appeared (Kokocińska \& Puziak, 2018). The first model was defined as German, to which the most similar situation 
occurred in Spain. This model is characterized by a distribution that is very similar to normal distribution, with only few leading regions. The second model was named Italian. This model features a characteristic bimodal distribution, with the size of both modes being comparable. The third model, called the British-French model, is also bimodal, but is characterized by a very rich capital region and a distribution similar to normal for the rest of the regions.

Observations of the income distribution for the V4 countries according to the abovementioned criteria lead to the following conclusions:

- firstly, none of the estimated income distribution is similar to normal. In all countries, bimodal distributions occurred, although evidently these bimodal distributions are different in magnitude and shift to the right. The highest values of subsequent modes, measured in thousands of euros, were observed in Poland, while slightly lower values were found for the Czech Republic and Slovakia;

- secondly, the second mode in Poland is the least numerous, which indicates a high polarization around several large cities. In other countries, the modes located to the right are more numerous and are not so far to the right in relation to the most numerous mode;

- thirdly, the subsequent shifts to the right did not take place in all economies due to the global financial crisis. The most regular shifts of the main mode to the right took place in the Czech Republic, with the most irregular shifts observed in Hungary and Slovakia. Moreover, in Hungary and Slovakia, GDP pc even declined in some years. The scale of the shifts between the years was different between selected years. However, in the majority of cases the largest shift to the right occurred immediately after joining the European Union. The smallest shift to the right or even a shift to the left was observed between the years 2008 and 2012, but after 2012, shifts to the right were observed;

- fourthly, the rate at which the right-hand modes were moving to the right was higher as compared to the modes located on the left. This polarization process has been gaining strength since 2004. The trend was less visible during the crisis, and then it grew stronger at the end of the researched period. Such an observation concerned all countries except for Hungary, where the mode located on the right side shifted to the left (comparing the years 2012 and 2015).

Comparing the results obtained for the V4 countries with the regional income distributions observed in the large European economies, it can be concluded that the V4 countries tend to follow the British-French model. This applies the most to Poland and the least to Hungary.

\section{CONCLUSION}

Regardless of whether a group of advanced economies or economies undergoing a systemic transformation is being taken into account, differences within their regional income distribution models can be expected. Bimodal or multimodal distributions are most dominant for all European economies, but the differences between modes in terms of income values vary between countries. Among the large European economies, the UK is the leader, and among V4 countries, Poland is the leader. 
The most similar aspects in terms of unimodal distribution were observed in Germany and in Spain. Among V4 countries, the economy of the Czech Republic stands out in terms of the highest level of competitiveness, which leads to the highest regularity in shifting to the right of the main mode and with declining growth rate of the second mode.

In many cases, in the catching-up countries the higher rate of economic growth occurs at the cost of the increasing regional inequalities. The creation of the second mode occurs around a large urban agglomeration (generally a capital city), where human capital is concentrated, which generates innovations and increase in the level of competitiveness.

For developing economies such as in the V4 countries, a clear remedy to decrease regional inequalities is the EU cohesion policy, which must in turn be supported by internal economic policy. It should also be borne in mind that the smaller countries suffered more from the global financial crisis, a finding which has been observed in terms of regional income distribution, including Hungary in particular.

This paper contributes to the existing literature in three ways. First, the study was conducted at the NUTS3 level, which is currently the lowest possible level of disaggregation. Secondly, the research covers both the period before and after the global financial crisis. Thirdly, the results of the internal convergence study have attempted to avoid bias, as they have been obtained by the use of methods previously tested in the group of Large European Economies.

A comprehensive approach to the study of internal convergence of a comparative nature is limited by the access to up-to-date statistical data at the NUTS3 level. The delay in publishing data affect the alacrity at which the presentation of research results is possible, with the result being limitations regarding the usefulness of such results for determining the economic policy of a country. The authors are convinced that there is a need to identify certain positive reference points which can take the form of the countries in which both types of convergence (external and internal) are occurring. The experiences of these countries should be used to formulate economic policy aimed at reducing regional inequalities. In the future, analogous analyses should be carried out for the remaining EU-28 countries, creating a "map" of convergence paths in order to facilitate the use of the best patterns that can be defined.

\section{References}

1. Abramovitz, M. (1986). Catching Up, Forging Ahead, and Falling Behind. The Journal of Economic History, 46 (2), 385-406. https://doi.org/10.1017/S0022050700046209

2. Baddeley, M. (2006). Convergence or divergence? The impacts of globalisation on growth and inequality in less developed countries. International Review of Applied Economics, 20 (3), 391-410. https://doi.org/10.1080/02692170600736250

3. Balcerzak, A. P., \& Pietrzak, B. M. (2017). Digital Economy in Visegrad Countries. Multiple-criteria Decision Analysis at Regional Level in the Years 2012 and 2015. Journal of Competitiveness, 9(2), 5-18. https://doi.org/10.7441/joc.2017.02.01

4. Barro, R. J., \& Sala-i-Martin, X. (1992). Convergence. The Journal of Political Economy, 100(2), 223-251. https://doi.org/10.2307/2138606 
5. Barro, R. J., \& Sala-I-Martin, X. (1991). Convergence Across States and Regions. Brookings Papers on Economic Activity, 22(1), 107-182. https://doi.org/10.2307/2534639

6. Bartkiewicz, P., Matejczuk, A., Kalinowski, H., Ośka, M., Regulski, A., \& Zawistowski, J. (2017). How do EU-15 Member States Benefit from the Cohesion Policy in the V4? Warsaw: Polish Ministry of Economic Development. Retrieved from https://www. funduszeeuropejskie.gov.pl/media/51506/Impact_and_results_of_cohesion_policy.pdf

7. Baumol, W. J. (1986). Productivity Growth, Convergence, and Welfare: What the Long-run Data Show. The American Economic Review, 76(5), 1072-1085. https://doi. $\operatorname{org} / 10.2307 / 1816469$

8. Baumol, W., \& Wolff, E. (1988). Productivity growth, convergence, and welfare: reply. The American Economic Review, 78(5), 1155-1159. https://doi.org/10.2307/1807175

9. De Long, B. (1988). Productivity Growth, Convergence, and Welfare: Comment. The American Economic Review, 78(5), 1138-1154.

10. Epanechnikov, V. (1969). Nonparametric estimation of a multidimensional probability density. Teoria Veroyatnosti i Primenen., 14(1), 156-161.

11. European Economic Community. (1987). Single European Act. Official Journal of the European Communities, (L 169), 1-19.

12. Heidenreich, N. B., Schindler, A., \& Sperlich, S. (2010). Bandwidth selection methods for kernel density estimation - A review of performance (December 16, 2010). Available at SSRN. https://doi.org/http://dx.doi.org/10.2139/ssrn.1726428

13. Horridge, M., \& Rokicki, B. (2018). The impact of European Union accession on regional income convergence within the Visegrad countries. Regional Studies, 52(4), 503-515. https:// doi.org/10.1080/00343404.2017.1333593

14. Ivanová, E., \& Čepel, M. (2018). The Impact of Innovation Performance on the Competitiveness of the Visegrad 4 Countries. Journal of Competitiveness, 10(1), 54-72. https:// doi.org/10.7441/joc.2018.01.04

15. Kisiala, W., Bajerski, A., \& Stepinski, B. (2017). Equalising or Polarising: the CentrePeriphery Model and the Absorption of EU Funds Under Regional Operational Programmes in Poland. Acta Oeconomica, 67(3), 413-434. https://doi.org/10.1556/032.2017. 67.3.6

16. Kokocińska, M., \& Puziak, M. (Eds.). (2018). Polska i Hiszpania na ścieżce konwergencji. Aspekty regionalne. Warszawa: Difin.

17. Kuc, M. (2017). Is the Regional Divergence a Price for the International Convergence? The Case of the Visegrad Group. Journal of Competitiveness, 9(4), 50-65. https://doi.org/10.7441/ joc.2017.04.04

18. Mankiw, N. G., Romer, P. M., \& Weil, D. N. (1992). A Contribution to the Empirics of Economic Growth Author. The Quarterly Journal of Economics, 107(2), 407-437. https://doi. $\operatorname{org} / 10.2307 / 2118477$

19. Nazrul, I. (1995). Growth Empirics: a Panel Data Approach. The Quarterly Journal of Economics, 110(4), 1127-1170. https://doi.org/10.2307/2946651 
20. Quah, D. (1993). Galton's Fallacy and Tests of the Convergence Hypothesis. The Scandinavian Journal of Economics, 95(4), 427-443. https://doi.org/10.2307/3440905

21. Sala-i-Martin, X. (2006). The World Distribution of Income: Falling Poverty and ... Convergence, Period. The Quarterly Journal of Economics, 121(2), 351-397. https://doi. org/10.1162/qjec.2006.121.2.351

22. Simionescu, M. (2014). Testing sigma convergence across EU-28. Economics and Sociology, 7(1), 48-60. https://doi.org/10.14254/2071-789X.2014/7-1/5

23. Williamson, J. G. (1965). Regional inequality and the process of national development: A description of the patterns. Economic Development and Cultural Change, 13(2), 1-84. https://doi. $\operatorname{org} / 10.1086 / 450136$

24. Wójcik, P. (2004). Konwergencja regionów Polski w latach 1990-2001. Gospodarka Narodowa, 11-12, 69-86.

25. Wójcik, P. (2016). Estymacja jądrowa w badaniach regionalnej konwergencji. Wiadomości Statystyc飞ne, 10 (665), 7-21.

26. Zambom, A. Z., \& Dias, R. (2013). A Review of Kernel Density Estimation with Applications to Econometrics. International Econometric Review (IER), 5 (1), 20-42. Retrieved from http://ideas.repec.org/a/erh/journl/v5y2013i1p20-42.html

\section{Contact information}

Prof. Malgorzata Kokocinska, Ph.D.

University of Zielona Góra

Faculty of Economics and Management

Department of International Economics

Poland

E-mail:m.e.kokocinska@gmail.com

Marcin Puziak, Ph.D.

Poznan University of Economics and Business

Faculty of Management

Department of Microeconomics

Poland

E-mail:marcin.puziak@ue.poznan.pl 